\title{
Marriage and Cohabitation: Qualitative Differences in Partnership Arrangements*
}

\author{
DANA HAMPLOVÁ** \\ Institute of Sociology, Academy of Sciences of the Czech Republic, Prague
}

\begin{abstract}
The article investigates the differences between marriage and non-marital cohabitation. The main perspective stems from the theory of the social exchange. The author concentrates on the narrow question of financial transfers between partners and presents the hypothesis that cohabitation should represent a lesser bond union because it does not protect investments into partnerships, and it should therefore be more egalitarian. However, this hypothesis is not confirmed by the data. Even though cohabitation is indeed a departure from the traditional family pattern, it is not a departure in the direction of greater egalitarianism but rather in the direction of a female breadwinner. The social exchange theory would predict that the shift towards the female breadwinner should be compensated by the greater participation of men in the household chores. This expectation is confirmed by the data.
\end{abstract}

Sociologický časopis/Czech Sociological Review, 2002, Vol. 38, No. 6: 771-788

\section{Introduction}

The increase in the number of people who live in the arrangement of non-marital cohabitation is a particularly visible change that has occurred in family life in the recent past. It is a subject that has been the focus of considerable attention in the media and in academic research, too. In these both these spheres cohabitation is often described as a modern alternative to marriage, an alternative that could be considered the logical outcome of the greater autonomy and freedom that individuals enjoy today in the modern society [e.g. Rabušic 1996, 2001]. In the early 1990s some Czech demographers began to predict that cohabitation would soon begin to spread throughout post-revolution, Czech society to a much greater degree [Vereš 1991].

There are two basic questions which relate to cohabitation and which are of particular interest from the sociological perspective. Though the two are tightly intertwined, it is of use, at least analytically, to distinguish between them. The first refers to the socio-demographic differences between those who enter into marriage and those who live in co-

\footnotetext{
* This research was enabled thanks to the support of grants no. A7-29101/01 and no. A7028101/01 from the Grant Agency Academy of Sciences CR and grant no. 403/02/1500 from the Grant Agency CR.

** Direct all correspondence to: Dana Hamplová, Institute of Sociology of the Academy of Sciences, Jilska 1, 11000 Prague 1, Czech Republic, tel. +420 22222 1663, e-mail: hamplova@soc.cas.cz
} 
habitation, and/i.e. the differences between those who enter directly into marriage and those who opt for cohabitation prior to marriage. The question in this case is whether the decision in favour of marriage or cohabitation is the result of relatively arbitrary values and preferences, and whether and how the decision is dependent on more 'objective' realities, e.g. the actual socio-economic standing of the people involved, their social group, class, or position on the 'marriage market', and whether then it is a matter of a relatively rational reaction to the circumstances people are living in [see Manning, Lichter 1996; Blackwell, Lichter 2000; Brown, Booth 1996; Carmichael 1995; Kiernan 2000].

The second question addresses the qualitative differences between marriage and cohabitation, i.e. what types of partnership do both types of union represent and what are their features. Many of the differences between marriage and cohabitation can be attributed to socio-economic differences, because people who live in a marriage arrangement simply differ from people who live in an arrangement of cohabitation. However, from the sociological perspective it is important to ask whether there also exist institutional differences that are intrinsic to the type of union. In essence this is a question of whether marriage or cohabitation lead by definition to different partnership arrangements, and whether and in what way the absence of a legal bond in the case of cohabitation has an effect on the partnership. This article focuses on the second of the two basic questions indicated above, and pays particular attention to examining differences in financial arrangements and economic factors.

\section{Qualitative differences between marriage and cohabitation}

Cohabitation and marriage have been the subject of comparative studies since the 1970s and 1980s, from which time attention has focused primarily on questions such as the stability of the union [Axinn, Thornton 1992; DeMaris, MacDonald 1993; Thomson, Collela 1992; DeMaris, Rao 1992; Hamplová 2001], satisfaction with the partnership [Brown, Booth 1996; Horwitz, White 1998] and, more recently, the division of labour within the union and economic aspects (financial transfers) [Brines, Joyner 1999; South, Spitze 1994; Rindfuss, VandenHeuvel 1990].

One of the key differences that exist between marriage and cohabitation is considered to be the difference in the division of labour (and the degree of specialisation of human capital) [Brines, Joyner 1999]. This perspective stems essentially from the theories both sociological [Blau 1964] and economic [Becker 1993] - of social exchange and it assumes that mutual dependency, exchange between partners, and the degree of joint investments they share, are what give the union its strength. The more partners depend on each other, the more they exchange, and the more they invest into the relationship, the stronger the union is.

Analyses of the shared investments of partners have concentrated for the most part on the question of investment into specialised human capital. It is of course clear that shared investment cannot be limited in this way and that it is necessary to also consider emotional involvement, trust, time, and the creation of a commonly shared world of mean- 
ing. ${ }^{1}$ However, investment into specialised capital draws attention for other reasons, not only because - unlike emotions or trust, for example - it can more easily be operationalised, but also because the basic changes in family and marriage behaviour that occurred in the second half of the 20th century are frequently ascribed to changes in the specialisation of human capital.

Discussions on this subject are based primarily on the work of Gary Becker, who applied economic analysis to the case of the family and household. According to Becker [1993] the division of labour within the household - specialisation in the allocation of time and in the accumulation of human capital - would appear even if all household members were identical and had the same comparative advantages. He argues that specialisation and division of labour is the most rational and efficient way to manage the household. This can be demonstrated through an example: identical members of a household can allocate time to both sectors and have the same investments into human capital. If they spend $\mathrm{x}$ hours in the market, the output will be same as if one of them spent twice as much time $(2 x)$ in the market and the other specialised completely in the household. However, both would be better off if one invested only in the household capital and the other only in the market capital. Investments into specialised human capital produce increasing returns and thereby provide a strong incentive for a division of labour because each member gains from a costless increase in household output. However, Becker adds that the degree of specialisation in the household will be lower if one of the labours (for example, household labour) is considered to be of less value or more boring.

From the perspective of investments into specialised capital and the division of labour, it is possible to assume that cohabitation and marriage are not identical [Brines, Joyner 1999]. Although the continually high rate of divorce in modern societies breaks down the reliability of marriage as a form of economic protection, there at least exist basic legal guarantees that the joint investments will not come up completely empty. This applies not only to direct financial deposits but also to the investments into non-remunerative human capital, which can only be used within the framework of the household, as persons who focus more on bringing up children may hope that their work will be taken into account when shared property is divided. ${ }^{2}$ If there are certain legal guarantees that the in-

\footnotetext{
${ }^{1}$ Peter L. Berger and Hans Kellner [1979] have pointed out the cognitive aspect of a marital relationship. Berger and Kellner unite the traditions of Weber, Mead and phenomenology and set out from the viewpoint that we live in a world that is founded on meanings mediated by society. Only through contact with others does man discover not only what the things that surround him/her actually are and what kind of place they occupy in the world, but also who he/she actually is. At the same time it is clear that a similarly socially rooted reality is quite fragile and requires continuous renewal and requires that our significant others continuously reassure us that things are as we believe they are. In their view people entering into marriage go through a certain form of re-socialisation, and as two strangers with different pasts stand faced with the task of constructing and maintaining a world that will make sense to both of them. In their view, in modern society the central relationship that participates in the maintenance of our world is marriage.

${ }^{2}$ De Santis and Livi Bacci [2001] emphasise that in societies with a high rate of divorce women can no longer rely on the economic security of marriage as in the past, and it is therefore rational that
} 
vestments into 'domestic capital' will be returned, as in marriage there indeed are, this does not mean that the partners must specialise in the different spheres, but space is created to allow for this possibility. ${ }^{3}$

Empirical findings from other countries support this theoretical assumption. In the case of unmarried couples, the difference in income between the partners is lower than that in the case of married couples, people specialise less in the labour or domestic sphere, fewer financial transfers occur between the partners, and there is a lower level of solidarity [Brines, Joyner 1999]. People living in cohabitation are less likely to merge their resources into joint bank accounts or share ownership of their houses [Blumstein, Schwartz 1983; Rindfuss, Vandenheuvel 1990, see Brines, Joyner 1999]. They are also less inclined to accept male and female roles [e.g. Rindfuss, VandenHeuvel 1990], are less concerned with the traditional division of roles in the household [e.g. South, Spitze 1994], and want fewer children (another joint investment). On the whole, the likelihood that they will establish strong and lasting relationships is also lower [e.g. Bumpass, Sweet 1989].

Brines and Joyner argue that cohabitation is an egalitarian type of union which involves a lower level of (financial) solidarity between partners because it is too risky to invest in specialised human capital and generally to invest in a partner. These authors are therefore among those who advocate the 'lesser bound perspective' on cohabitation, and view cohabitation as a union that lies in between marriage and LAT (Living Apart Together).

Even though this theoretical approach anticipates a causal relationship, the direction of influence need not only be one-way. It is equally possible that people choose to cohabit because they do not want to pool their resources and prefer a more individualistic arrangement. That there are fewer transfers between partners in cohabitation may also stem from the fact that it is mostly young people who cohabit. They may not wish to 'invest' in the partner and view cohabitation as a phase prior to 'serious involvement', or they may not have a regular income. However, the fact that we are unable to determine any pos-

they would try to develop human capital that they could use on the labour market [ibid., pp. 22-23]. Even though in this regard the strength of marriage is eroding, what is of significance is that in comparison with cohabitation it nonetheless still provides some guarantees. This does not mean that modern marriage provides large guarantees and is the ideal environment for the development of the specialisation of human capital, but cohabitation is even worse than marriage in this regard.

${ }^{3}$ Do marriage and cohabitation differ in the degree of other, for example, emotional investments? The answer to this question is more complicated, as the degree of psychological investment into a relationship, unlike income, the number of children, or the relative stability of the union, is difficult to measure. Equally, with the aid of standard qualitative methods it is difficult to verify whether marriage and cohabitation differ in terms of how much the re-socialisation of partners occurs in both types of union. Some studies could suggest that marriage and cohabitation do differ in the degree of emotional support (see Stack and Eshleman 1998 - a study on professed satisfaction in 17 countries). It is indeed possible to assume that the insecurity that is tied to the future of the union, or the simple fact that cohabitation falls apart more often than marriage, could lead to a lower degree of emotional investment and less mutual accommodation, but more general thoughts on this subject could easily slide into pure speculation. 
sible causality (cause and consequence) does not affect the actual connection between marriage, cohabitation and financial transfers. The question is basically whether cohabitation is indeed a 'lesser bond', and not whether people actually choose cohabitation owing to a lower level of commitment.

\section{Data and methodology $y^{4}$}

The question is whether any of these findings can be confirmed in the case of Czech society, whether in the Czech case marriage and cohabitation also differ with respect to financial solidarity, and whether cohabitation represents a union with fewer transfers between partners. Differences between marriage and cohabitation were tested on data from the survey 'Ten Years of Social Transformation' (TYST), conducted in 1999 by the Institute of Sociology of the Academy of Sciences of the Czech Republic (with 4744 respondents). The first part of the following empirical analysis briefly describes the distribution of cohabitation found in this survey, but the second part of the empirical analysis is the main focus, as it concentrates on the question of the relative financial contribution to the household and division of labour. I have employed log-linear modelling for the purpose of addressing this question.

In the survey, if the respondent indicated another member of the household as his/her partner and at the same time stated that he/she was married, the person was considered to be living in a marriage. If the respondent indicated another member of the household as his/her partner and at the same time stated that he/she was single, divorced, or widowed, the person was considered to be living in cohabitation. Respondents without partners were excluded from the analysis, which reduced the sample to 3104 respondents and their partners (or 3104 couples, of which 280 are living in cohabitation).

\subsection{Distribution of the living arrangements - descriptive statistics}

The TYST survey indicates that at present 6 per cent of the population ${ }^{5}$ in the Czech Republic live in cohabitation; among people aged 30 and under the proportion may be es-

\footnotetext{
${ }^{4}$ This article is limited in that it cannot take into account the magnitude of the respective transfers, which would be necessary for creating a complete picture. It was possible to work with only a very rough indication of transfers and it is clear that their magnitude is also fundamental, but we are unable to say, for example, whether the transfers in marriage and cohabitation are on more or less the same level, or if the transfers in cohabitations are generally lower than those in marriage. Another limitation to the article is that it cannot take into consideration the duration of the union and how the economics of the household influence the probability that the cohabiting couple will enter marriage or that the union will be dissolved and how the probability of marriage influences the financial transfers among partners.

${ }^{5}$ According to the Family and Fertility Survey, roughly $7 \%$ of women aged $15-44$ were living in unmarried cohabitation.
} 
Table 1. Percentage of respondents (men and women) living in non-married cohabitation (\%)

\begin{tabular}{cc}
\hline Age group & Percentage of respondents in cohabitation \\
\hline-20 & 4.5 \\
$20-24$ & 10.2 \\
$25-29$ & 10.9 \\
$30-34$ & 6.8 \\
$35-39$ & 4.2 \\
$40-44$ & 5.1 \\
$45-49$ & 3.3 \\
$50-59$ & 4.6 \\
$60+$ & 2.1 \\
\hline
\end{tabular}

Source: Ten Years of Social Transformation.

Table 2. Percentage of women living in non-married cohabitation (\%)

\begin{tabular}{cc}
\hline Age group & Percentage of women in non-married cohabitation \\
\hline-20 & 11.2 \\
$20-24$ & 10.1 \\
$25-29$ & 8.3 \\
$30-34$ & 8.2 \\
$35-39$ & 5.4 \\
$40-44$ & 5.0 \\
\hline
\end{tabular}

Source: Family and Fertility Survey.

timated as up to 10 per cent (Table 1). However, the higher proportion of cohabitation among young people aged 25 and under is mainly due to the fact that cohabitation serves as a premarital 'test'. These results correspond with findings from the Family and Fertility Survey data (Table 2). The ISSP 2001 indicates a somewhat higher rate of cohabitation for the population, at 10 per cent, and reports that the proportion of people aged 30 and under who are living in cohabitation is approximately 15 per cent.

\subsection{Differences between marriage and cohabitation}

A test was made of the basic hypothesis that there is a difference between marriage and cohabitation, and that these two partnership arrangements differ with respect to the degree of financial transfers occurring between partners. Specifically I have sought to determine whether there is a difference between these arrangements or whether cohabitation is simply an informal marriage that differs from a formal marriage only in legal terms: if cohabitation indeed represents a more egalitarian union with fewer transfers, this means that both partners will more often than in marriage contribute to the household in equal part, 
Table 3. Economic activity of partners in marriage or in cohabitation

\begin{tabular}{lccc}
\hline Economic activity & & Marriage & Cohabitation \\
\hline Inactive male, active female & abs. & 25 & 10 \\
& in \% & $\mathbf{1 . 2}$ & $\mathbf{4 . 7}$ \\
Both active & abs. & 1734 & 167 \\
\multirow{2}{*}{ Active male, inactive female } & in \% & $\mathbf{8 0 . 9}$ & $\mathbf{7 8 . 8}$ \\
& abs. & 384 & 35 \\
& in \% & $\mathbf{1 7 . 9}$ & $\mathbf{1 6 . 5}$ \\
\hline
\end{tabular}

Source: Ten Years of Social Transformation 1999.

Statistically significant differences at the level 0.00 (chi-square test of table homogeneity).

Table 4. 'Who in your household ensures the main income?'

\begin{tabular}{lrrrr}
\hline \multirow{2}{*}{$\begin{array}{l}\text { Financial support } \\
\text { in the household }\end{array}$} & \multicolumn{2}{c}{ Marriage } & \multicolumn{2}{c}{ Cohabitation } \\
\hline Mostly the male & 1346 & 48.2 & 105 & 37.8 \\
More the male & 363 & 13.0 & 43 & 15.5 \\
Both & 900 & 32.2 & 101 & 36.3 \\
More the female & 104 & 3.7 & 9 & 3.2 \\
Mostly the female & 57 & 2.0 & 20 & 7.2 \\
Someone else & 24 & 0.9 & - & - \\
Total & 2794 & 100.0 & 278 & 100.0 \\
\hline
\end{tabular}

Source: Ten Years of Social Transformation.

Statistically significant differences at the level 0.00 (chi-square test of table homogeneity).

and if marriage is more benign towards financial transfers and represents a lower risk in respect to the financial setting, the division of labour within the marriage should be higher than in cohabitation.

Basic descriptive statistics confirm that differences in the division of labour between marriage and cohabitation do exist. Table 3 presents the simple ratio of economically active men and women in marriage and in cohabitation. While this is a rough indicator, even in these basic contours statistically significant differences between marriage and cohabitation appear, though not in the direction of greater egalitarianism but rather towards a model of an economically active woman and inactive man. The difference is small (a 3.5 per cent difference between marriage and cohabitation) but it represents an increase of more than 300 per cent. As we have a large sample, we can rely on a relatively narrow confidence interval and statistical tests, and may expect the difference to be non-random. If we take into consideration how the respondents evaluate the relative financial contribution to the running of the household (see Table 4) the results are even more pronounced.

This adds another interesting aspect to the subject. Oppenheimer and Nelson [1997], Clarberg [1999], and Blackwell and Lichter [2000] have presented the argument that co- 
habitation represents an alternative partnership for couples in which the male partner is not sufficiently attractive from the economic viewpoint. Their view thus refers back to the socio-demographic differences between those who enter marriage and those who live in cohabitation. They do not expect that there should be intrinsic differences between marriage and cohabitation, but emphasise that different types of couples choose marriage and cohabitation. If entry into marriage is closely tied to the economic potential of the male as they claim, then cohabitation need not be more egalitarian, but should represent a type of union in which women more often hold the main economic responsibility for the household.

Descriptive statistics of course provide only a very rough picture of things, and it is clear that it is not possible to judge the relative contribution to the family budget only with regard to whether the couple lives in a marriage or in cohabitation. A significant role is played by the objective remunerative potential of the partners, especially with respect to education and educational homogamy, hypergamy or hypogamy. However, it is also likely that the meaning of cohabitation varies among different social groups. Cohabitation among people with higher education can represent a more egalitarian and 'modern' union, while among people with lower education it may be a living arrangement for couples where the man is economically unattractive. For this reason I have created a log-linear model that not only takes into consideration the absolute differences between marriage and cohabitation but also encompasses the education of both partners and the combination of the two.

\section{Log-linear models}

Owing to incomplete data on income I started out in the analyses with the question: 'Who in your household ensures the main financial income?' This question does not reflect only the earning potential of the partners but also their promptness in financially contributing to the household. This is especially important when trying to investigate willingness to invest in the partner. Owing to the size of the sample the original five-point scale needed to be re-coded into three basic categories (more the male, both together, more the female). For the same reason it was also necessary to decrease the number of educational categories, and only three basic levels are included in the analyses: without graduation, with graduation, post-secondary (i.e. university or other post-secondary). Also, 25 cases had to be left out owing to missing information on the education of one of the partners, and 79 cases owing to missing information on who secures the financial income of the household. ${ }^{6}$

The saturated model, which serves as the basis for the evaluations of the more parsimonious models, incorporates the interaction of a fourth order between cohabitation, relative contribution to the family budget, the education of the man and the education of

\footnotetext{
${ }^{6}$ In the table five fields have not been filled in (out of the total 81 ), and for this reason the sample was expanded by five fictitious couples (with a weight of 0.5 ).
} 
Table 5. Overview of log-linear models used (with the variable finan - relative financial contribution to the running of the household)

\begin{tabular}{|c|c|c|c|c|}
\hline Model & Effects used: & G & Df & $\mathrm{P}$ \\
\hline $\begin{array}{l}\text { Saturated model } \\
\text { (includes all possible effects } \\
\text { and interactions) }\end{array}$ & $\begin{array}{l}\text { cohabitation*finan*edu_f*edu_m; } \\
+ \text { all effects of a lower class }\end{array}$ & & & \\
\hline $\begin{array}{l}\text { Model } 1 \\
\text { (includes only interaction } \\
\text { between the type of union } \\
\text { and financial contribution) }\end{array}$ & $\begin{array}{l}\text { cohabitation*finan; cohabitation, } \\
\text { edu_f, edu_m, finan }\end{array}$ & 1167.49 & 44 & 0.00 \\
\hline $\begin{array}{l}\text { Model } 2 \\
\text { (Model } 1+\text { interaction } \\
\text { between female education } \\
\text { and financial contribution) }\end{array}$ & $\begin{array}{l}\text { edu_f*finan, cohabitation*finan; } \\
\text { cohabitation, edu_f, edu_m, finan }\end{array}$ & 1143.18 & 40 & 0.00 \\
\hline $\begin{array}{l}\text { Model } 3 \\
\text { (Model } 2+\text { interaction } \\
\text { between male education and } \\
\text { financial contribution) }\end{array}$ & $\begin{array}{l}\text { edu_m*finan,edu_f*finan, } \\
\text { cohabitation*finan; cohabitation, } \\
\text { edu_f, edu_m, finan }\end{array}$ & 1132.14 & 36 & 0.00 \\
\hline $\begin{array}{l}\text { Model } 4 \\
\text { (Model } 3+\text { interaction } \\
\text { between male and female } \\
\text { education) }\end{array}$ & $\begin{array}{l}\text { edu_m*edu_f,edu_m*finan,edu_f*finan, } \\
\text { cohabitation*finan; cohabitation, edu_f, } \\
\text { edu_m, finan }\end{array}$ & 22.37 & 32 & .8972 \\
\hline
\end{tabular}

$\mathrm{G}$ - likelihood ratio chi-square, Df - degree of freedom, P - statistical significance edu_m - education of the man, edu_f - education of the woman, finan - relative contribution to the family budget, cohabitation - living in a marriage or in cohabitation Source: Ten Years of Social Transformation

the woman. I have chosen to include into all tested models the interaction between relative financial contribution to the family budget and type of the union since this is the question of main interest. The most parsimonious model, Model 1, assumes that the contribution to the family budget depends only on the type of partnership, while the other factors are independent, which would mean that the financial setting of the household depends only on the partnership arrangement and no other influence plays a role. Model 2 considers in addition the connection between the education of the woman and the contribution to the family budget, which would make sense if the earning potential of women were the key factor, without regard to the education level of the man. Model 3 adds the influence of the education of the man, which would mean that the financial contribution depends on the type of union, the education of the woman, and the education of the man. None of these three models is statistically acceptable (see Table 5).

Only Model 4, which also includes the educational homogamy of the couple, cannot on the basis of the chi-square and likelihood ratio test be rejected. This model takes into consideration the education of the man, the education of the woman, and whether they live in a marriage, and the impact of these factors on the relative contribution to the family bud- 
Table 6. Expected count from Model 4 with the variable finan (relative financial contribution to the household)

\begin{tabular}{|c|c|c|c|c|c|}
\hline \multirow{2}{*}{$\begin{array}{l}\text { type of } \\
\text { cohabitation }\end{array}$} & \multirow{2}{*}{$\begin{array}{l}\text { relative } \\
\text { financial } \\
\text { contribution }\end{array}$} & \multirow[t]{2}{*}{$\begin{array}{l}\text { education of } \\
\text { the man }\end{array}$} & \multicolumn{3}{|c|}{$\begin{array}{l}\text { education of } \\
\text { the woman }\end{array}$} \\
\hline & & & without grad. & with grad. & higher \\
\hline \multirow[t]{9}{*}{ marriage } & \multirow[t]{3}{*}{ more the male } & without grad. & 721.1 & 248.37 & 16.2 \\
\hline & & with grad. & 119.85 & 280.1 & 40.64 \\
\hline & & higher & 28.92 & 125.61 & 105.03 \\
\hline & \multirow[t]{3}{*}{ both together } & without grad. & 403.25 & 130.34 & 16.04 \\
\hline & & with grad. & 60.63 & 132.98 & 36.39 \\
\hline & & higher & 9.36 & 38.14 & 60.14 \\
\hline & \multirow[t]{3}{*}{ more the female } & without grad. & 55.48 & 33.24 & 5.91 \\
\hline & & with grad. & 7.62 & 30.97 & 12.25 \\
\hline & & higher & 0.61 & 4.6 & 10.49 \\
\hline \multirow{9}{*}{$\begin{array}{l}\text { non-married } \\
\text { cohabitation }\end{array}$} & \multirow[t]{3}{*}{ more the male } & without grad. & 61.61 & 21.22 & 1.38 \\
\hline & & with grad. & 10.24 & 23.93 & 3.47 \\
\hline & & higher & 2.47 & 10.37 & 8.97 \\
\hline & \multirow[t]{3}{*}{ both together } & without grad. & 42.96 & 13.89 & 1.71 \\
\hline & & with grad. & 6.46 & 14.17 & 3.88 \\
\hline & & higher & 1.0 & 4.06 & 6.41 \\
\hline & \multirow[t]{3}{*}{ more the female } & without grad. & 9.91 & 5.94 & 1.06 \\
\hline & & with grad. & 1.36 & 5.53 & 2.19 \\
\hline & & higher & 0.11 & 0.82 & 1.87 \\
\hline
\end{tabular}

Source: Ten Years of Social Transformation.

get. The expected counts of Model 4 are presented in Table 6. The interaction of the higher order does not improve the model in any statistically significant way, which in other words means that the influence of the living arrangement does not vary among educational groups and the trends are the same for all three educational categories. This is an important finding as it means that cohabitation does not from the financial viewpoint represent a different type of union for people with different educational backgrounds. The claim that cohabitation may represent a 'modern egalitarian' type of union among the more educated, and a 'union with a financially unattractive man' among the less educated, is not supported in the data, and trends connected with cohabitation seem to be general. This does not mean that the concept of cohabitation is identical among well and less educated people; our data does however indicate that the financial arrangements do not differ.

\section{Interpretation of the selected model}

As we have now selected the model that fits the data, we can turn to the main question of whether there is any difference between marriage and cohabitation in the relative financial contribution to the family budget ('Who in your household ensures the main financial income?'), and if so, what the difference is. The expected counts and parameters estimates 
Table 7. Parameter estimates from Model 4 with the variable finan (relative financial contribution to the household)

\begin{tabular}{|c|c|c|c|c|c|c|}
\hline \multicolumn{3}{|l|}{ main effect and two-way } & \multirow{2}{*}{$\begin{array}{l}\text { parameter } \\
\text { estimate }\end{array}$} & \multirow[b]{2}{*}{ Z-value } & \multicolumn{2}{|c|}{ asymptotic $95 \%$ CI } \\
\hline effects & & & & & lower & upper \\
\hline constant & & & 2,1942 & & & \\
\hline marriage & & & 2,46 & 28,34 & 2,29 & 2,63 \\
\hline female educ. - without grad. & & & $-1,2829$ & $-7,28$ & $-1,64$ & $-0,94$ \\
\hline female educ. - grad. & & & 0,1789 & 1,57 & $-0,04$ & 0,4 \\
\hline male educ. - without grad. & & & $-1,8689$ & $-10,01$ & $-2,23$ & $-1,5$ \\
\hline male educ. - grad. & & & $-0,9495$ & $-6,64$ & $-1,23$ & $-0,67$ \\
\hline finan - more the woman & & & $-1,5665$ & $-4,92$ & $-2,19$ & $-0,94$ \\
\hline finan - equall & & & $-0,3369$ & $-1,85$ & $-0,69$ & 0,02 \\
\hline female educ. - without grad. & * & male educ. - without grad. & 5,0851 & 21,61 & 4,62 & 5,55 \\
\hline female educ. - without grad. & * & male educ. - grad. & 2,3711 & 11,15 & 1,95 & 2,79 \\
\hline female educ.- grad. & * & male educ. - without grad. & 2,5507 & 13,04 & 2,17 & 2,93 \\
\hline female educ. - grad & * & male educ. - grad. & 1,7515 & 11,27 & 1,45 & 2,06 \\
\hline finan - more the woman & * & male educ. - without grad. & 1,2961 & 4,25 & 0,7 & 1,89 \\
\hline finan - more the woman & * & male educ. - grad. & 1,1053 & 3,73 & 0,52 & 1,69 \\
\hline finan - equally & * & male educ. - without grad. & 0,5472 & 3,7 & 0,26 & 0,84 \\
\hline finan - equally & * & male educ. - grad. & 0,447 & 3,06 & 0,16 & 0,73 \\
\hline finan - more the woman & * & female educ. - without grad. & $-1,5567$ & $-5,77$ & $-2,09$ & $-1,03$ \\
\hline finan - more the woman & * & female educ. - grad. & $-1,0033$ & $-4,1$ & $-1,48$ & $-0,52$ \\
\hline finan - equally & * & female educ. - without grad. & $-0,5708$ & $-3,61$ & $-0,88$ & $-0,26$ \\
\hline finan - equally & * & female educ. - grad. & $-0,6344$ & $-4,27$ & $-0,93$ & $-0,34$ \\
\hline finan - more the woman & * & marriage & $-0,7376$ & $-3,35$ & $-1,17$ & $-0,31$ \\
\hline finan - equally & * & marriage & $-0,2207$ & $-1,59$ & $-0,49$ & 0,05 \\
\hline
\end{tabular}

Source: Ten Years of Social Transformation.

from Model 4 confirm a difference. However, it is not egalitarianism that is typical for cohabitation; the odds that partners will equally contribute to the household budget do not differ according to the living arrangements $(z$-score $=1.59)$. The data do not indicate that people in cohabitation are less willing to transfer financial resources to the partner because it is a riskier partnership arrangement that does not protect (financial) investments in the partner. Our main hypothesis regarding cohabitation has therefore not been confirmed.

However, living in cohabitation does increase the odds that the main contributor to the family budget is a woman. A simple odds ratio based on the expected counts is 1.93 (z-score: 3.35). This means that the chance that the woman will be the 'breadwinner' is nearly twice as high as for those living in cohabitation. Such a result strongly confirms the tendency that has already been revealed in the cross-tables and shows that cohabitation is often connected with a departure from the traditional family; the shift is not however in the direction of egalitarianism, but rather towards a larger number of female breadwinners.

We have already stated that trends connected with cohabitation do not differ among various educational groups. It is also true that education does not express itself differently 
in marriage and cohabitation. In other words, educational attainments are connected with identical trends regardless of whether the person lives in marriage or cohabitation. Education behaves essentially according to expectations: men with a university (or post-secondary) degree have the highest odds of being the breadwinners in the family, and women with lower education have higher odds that they will be supported by men. The odds ratio of being the breadwinner for men with post-secondary education in comparison with men without high school is 1,39 (z-score: -4.25 ). This basically means that men with post-secondary education have a 40 per cent higher chance of being the breadwinner than men without high school. The probability of being the breadwinner in the case of men with postsecondary education, in comparison with high-school graduates, is 1,36 (z-score: -3.73).

The data thus indicate that cohabitation is really a departure from the family characterised by a traditional division of labour, and not necessarily in the direction of greater equality, but rather towards an arrangment in which the female is the breadwinner. This would seem to agree with the hypothesis that cohabitation is a type of union in which the male is economically less attractive (or is unwilling to contribute to the household) and consequently would seem to correspond more to the results of some foreign studies, e.g. those of Clarberg [1999] or Blackwell and Lichter [2000].

\subsection{Trade-offs in the division of labour}

The question that arises in this case is whether the shift towards a union with a female breadwinner also holds consequences for the division of labour in the household. Social exchange theories would indicate a positive answer to this question. I have therefore tested for differences leading either towards greater egalitarianism (neither of the partners is willing to invest more into labour in the household) or towards a hypothesis that some men compensate their lower financial contribution through a greater share in household chores. According to Blackwell and Lichter [2000] homogamy is the social norm in partner selection. If, however, the rule of homogamy is broken, it happens that people compensate a lack in one sphere by offering their partner upward mobility in another sphere. ${ }^{7}$

The models agree with those in the preceding section. The variable of relative financial contribution (finan) has however been replaced with the variable of who runs the household (househ), ${ }^{8}$ and the original five-point scale has been re-coded into a three-point scale (more the male, both together, more the female). The first three models correspond to the first three from the previous section and again are not statistically acceptable. Only Model 4A, which adds the interaction between the education of the male and the female, is suitable (see Table 8).

\footnotetext{
${ }^{7}$ As a specific example they cite the combination of educational and racial hypergamie and hypogamie, in which people with a lower level of education substitute their relative 'insufficiency" with a higher status from the perspective of race.

${ }^{8}$ Also in this table five fields have not been filled in (out of the total 81), and for this reason the sample was expanded by five fictitious couples (with a weight of 0.5 ).
} 
Table 8. Overview of log-linear models used (with the variable househ - the relative share in the running of the household)

\begin{tabular}{|c|c|c|c|c|}
\hline Model & Effects used: & G & Df & $\mathrm{P}$ \\
\hline Model 4A & $\begin{array}{l}\text { edu_m*edu_f,edu_m*househ,edu_f*h } \\
\text { ouseh, cohabitation*househ; } \\
\text { cohabitation, edu_f, edu_m, househ }\end{array}$ & 37.6764 & 32 & 0.2255 \\
\hline Model 5A & $\begin{array}{l}\text { edu_m*edu_f, cohabitation*househ; } \\
\text { cohabitation, edu_f, edu_m, househ }\end{array}$ & 42.8680 & 40 & 0.3492 \\
\hline Model 6A & $\begin{array}{l}\text { edu_m*edu_f,edu_m*househ,edu_f* } \\
\text { househ, cohabitation, edu_f, edu_m, } \\
\text { househ }\end{array}$ & 56.2111 & 34 & 0.0097 \\
\hline
\end{tabular}

Source: Ten Years of Social Transformation.

Surprisingly, parameter estimates show no statistical significance between the division of the household chores and education. This conclusion is true for both the education of the male and the female. As the data indicate that education does not have any explanatory strength, in the next step the interaction between education and the division of labour has been removed (Model 5A). This model saves 8 degrees of freedom and and the statistical test shows that it fits the data even better. Model 6A uses an opposite perspective and eliminates the interaction between the running of the household and the living arrangement, but it includes the interaction between household responsibility and education. It therefore tests whether the difference between marriage and cohabitation is not based only on the different educational composition of the unions. However, it is not satisfactory from the point of view of the statistical test and therefore it may be concluded that the data do not reveal any connection between household chores and education. Model 4A and Model 5A could both be used for the interpretation since they both fit the data well, but I have chosen Model 4A because it corresponds to Model 4 used in the analyses on financial responsibility for the household.

\section{Interpretation of the selected model}

Even in this case, the data confirm a basic difference between the marriage and cohabitation: cohabitation appears to be slightly more egalitarian. The odds ratio that the division of household chores in cohabitation will be egalitarian is 1.26 (z-score 4.33). This means that the chance of sharing the household chores equally is around 26 percent higher for people living in cohabitation than for married people. However, the most profound difference is found in the odds that the man will be responsible for the running of the household (odds ratio is 2,63; z-score 4.33). No other interactions in the division of household responsibility were revealed in the interpreted models.

It should be added with regard to both models (Model 4 and Model 4A) interpreted here that these are relative differences between marriage and cohabitation. In no case then does this mean that among unmarried pairs the dominant type of couples are those 
Table 9. Expected frequencies in Model 4A with the variable household (the relative share in the running of the household)

\begin{tabular}{|c|c|c|c|c|c|}
\hline & who looks & & & education & he woman \\
\hline & $\begin{array}{l}\text { the } \\
\text { household }\end{array}$ & of the man & without grad. & with grad. & higher \\
\hline marriage & $\begin{array}{l}\text { more the } \\
\text { male }\end{array}$ & without grad. & 42.99 & 11.21 & 0.9 \\
\hline & & with grad. & 8.13 & 14.15 & 2.40 \\
\hline & & higher & 2.12 & 6.88 & 6.35 \\
\hline & $\begin{array}{l}\text { both } \\
\text { together }\end{array}$ & without grad. & 325.07 & 117.91 & 12.39 \\
\hline & & with grad. & 53.05 & 128.45 & 28.56 \\
\hline & & higher & 9.77 & 44.06 & 53.21 \\
\hline & $\begin{array}{l}\text { more the } \\
\text { female }\end{array}$ & without grad. & 817.93 & 286.03 & 25.33 \\
\hline & & with grad. & 128.11 & 299.06 & 56.05 \\
\hline & & higher & 26.31 & 114.40 & 116.49 \\
\hline cohabitation & $\begin{array}{l}\text { more the } \\
\text { male }\end{array}$ & without grad. & 10.28 & 2.68 & 0.22 \\
\hline & & with grad. & 1.94 & 3.39 & 0.58 \\
\hline & & higher & 0.51 & 1.65 & 1.52 \\
\hline & $\begin{array}{l}\text { both } \\
\text { together }\end{array}$ & without grad. & 36.86 & 13.37 & 1.40 \\
\hline & & with grad. & 6.02 & 14.57 & 3.24 \\
\hline & & higher. & 1.11 & 5.00 & 6.03 \\
\hline & $\begin{array}{l}\text { more the } \\
\text { female }\end{array}$ & without grad. & 66.82 & 23.37 & 2.07 \\
\hline & & with grad. & 10.47 & 24.43 & 4.58 \\
\hline & & higher & 2.15 & 9.35 & 9.52 \\
\hline
\end{tabular}

Source: Ten Years of Social Transformation.

in which the woman is the main breadwinner in the family and the man looks after the household. Analyses only show that among unmarried couples it occurs with somewhat greater frequency that the woman financially looks after the household and the man participates more in the housework. It must also be mentioned that these analyses were done on aggregate data.

\section{Results and conclusion}

In the previous analyses I tried to test a hypothesis that cohabitation and marriage are not identical from the point of social exchange, especially as regards financial transfers, division of labour and investments in specialised human capital. The hypothesis was that cohabitation does not protect investments as well as marriage and thus should lead to fewer finan- 
Table 10. Parameter estimates from Model 4A with the variable household (the relative share in the running of the household)

\begin{tabular}{|c|c|c|c|c|c|c|}
\hline \multicolumn{3}{|l|}{ main effect and two-way effects } & \multirow{2}{*}{$\begin{array}{c}\text { parameter } \\
\text { estimate }\end{array}$} & \multirow[b]{2}{*}{ Z-value } & \multicolumn{2}{|c|}{ asymptotic $95 \% \mathrm{C}$} \\
\hline & & & & & lower & upper \\
\hline constant & & & 4,7578 & & & \\
\hline cohabitation & & & $-2,5048$ & $-29,76$ & $-2,67$ & $-2,34$ \\
\hline female educ. - without grad. & & & $-1,4878$ & $-8,36$ & $-1,84$ & $-1,14$ \\
\hline female educ. - grad. & & & $-0,0180$ & $-0,16$ & $-0,24$ & 0,21 \\
\hline male educ. - without grad. & & & $-1,5257$ & $-8,63$ & $-1,87$ & $-1,18$ \\
\hline male educ. - grad. & & & $-0,7314$ & $-5,44$ & $-1,00$ & $-0,47$ \\
\hline household - more the man & & & $-2,9088$ & $-9,14$ & $-3,53$ & $-2,28$ \\
\hline household - equal & & & $-0,7835$ & $-5,87$ & $-1,04$ & $-0,52$ \\
\hline female educ. - without grad. & & male educ. - without grad. & 4,9626 & 21,44 & 4,51 & 5,42 \\
\hline female educ. - without grad. & & male educ. - grad. & 2,3144 & 10,98 & 1,90 & 2,73 \\
\hline female educ. - grad. & & male educ. - without grad. & 2,4421 & 12,76 & 2,07 & 2,82 \\
\hline female educ. - grad & & male educ. - grad. & 1,6923 & 11,09 & 1,39 & 1,99 \\
\hline household - more the man & * & male educ. - without grad. & $-0,4288$ & $-1,32$ & $-1,06$ & 0,21 \\
\hline household - more the man & * & male educ. - grad. & $-0,2401$ & $-0,75$ & $-0,87$ & 0,39 \\
\hline household - equal & & male educ. - without grad. & 0,0679 & 0,47 & $-0,22$ & 0,35 \\
\hline household - equal & * & male educ. - grad. & 0,1090 & 0,75 & $-0,17$ & 0,39 \\
\hline household - more the man & * & w - without grad. & 0,3917 & 1,02 & $-0,60$ & 1,15 \\
\hline household - more the man & * & w - grad. & 0,0983 & 0,27 & $-0,61$ & 0,81 \\
\hline household - equal & * & female educ. - without grad. & $-0,2072$ & $-1,31$ & $-0,52$ & 0,10 \\
\hline household - equal & * & female educ. - grad & $-0,1706$ & $-1,15$ & $-0,46$ & 0,12 \\
\hline household - more the man & * & cohabitation & 1,0743 & 4,33 & 0,59 & 1,56 \\
\hline household - equal & * & cohabitation & 0,3279 & 2,33 & 0,05 & 0,60 \\
\hline
\end{tabular}

Source: Ten Years of Social Transformation.

cial transfers between the partners and less specialisation of roles. Specialisation requires security and the certainty that the contract will not be broken, especially if we are speaking of the long-term specialisation of human capital. Since cohabitation provides less legal security and less of a possibility to enforce the contract it can be expected that the partners will be less willing to invest in the relationship and in the capital that cannot be used in the labour market. Therefore, it could be expected that cohabitation would operate in a more egalitarian modus. This hypothesis was not confirmed by the data. Cohabitation does not appear to be more egalitarian than marriage with respect to the financial support of the household and financial transfers among the partners. However, data showed a significant difference among the marriage and cohabitation in the shift towards the female breadwinner. Cohabitation thus does seem to represent a departure from the traditional pattern, but more towards a female breadwinner than towards an egalitarian arrangement.

We cannot discern from the data whether the significant shift towards the female breadwinner is voluntary or involuntary, and we are also unable to say whether cohabitation is in such cases opted for by women, men or both. It could be expected that women 
are less willing to marry men who are not able to support the family, and thus choose to live in cohabitation, as it is easier to dissolve the partnership should they meet a 'better match'. This would agree with the theories of Oppenheimer, Nelson, or Clarberg, and generally with Anglo-American research showing that cohabitation represents an alternative partnership for couples in which the male partner is not sufficiently attractive from the economic viewpoint. However, to make such a conclusion would not be apt since the data do not answer the questions of motivation and causality. It may also be possible that cohabitation in these cases is the choice of men who feel inadequate and expect that they should not marry until they are able to meet the societal expectations of being able to support their families. Advocates of cohabitation as the 'modern' way of life would also probably object to both these explanations and would present the argument that cohabitation is more often chosen by non-conformist couples who have made a decision to abandon the traditional pattern, both in the sense of the legal recognition of the union and in terms of gender roles. In such cases the shift towards the female breadwinner would be the voluntary and sought-after mode of organisation in the household.

It could be expected that the meaning of cohabitation would vary in different social strata and that the 'non-conformist' and 'economically less attractive male' theories might be applicable for different social groups. However, the data do not confirm this. It is not possible to conclude that among people with higher education cohabitation represents a more egalitarian and 'modern' union, while among people with lower education it may be a living arrangement for couples where the man is economically unattractive. There are no significant differences in trends connected with cohabitation among different educational groups in the data. This does not mean that the conceptual idea of cohabitation is identical for all educational groups, but the trends connected with the household economics of cohabitation are the same. Thus it cannot be said that cohabitation is an 'egalitarian' partnership among well-educated people.

Social exchange theories also predict that lower earning potential or less of a willingness to contribute to the household should be compensated in a different sphere. From the perspective of household economics the expectation is that this compensation should occur in the sphere of housework and that the lower relative financial benefit should be compensated by higher participation in household chores. The data did in fact confirm this expectation, and on the aggregate level the shift towards a female breadwinner in the arrangement of cohabitation was accompanied by a higher proportion of men taking the main responsibility for running the household. Again, how much this is a voluntary move and how much it is a result of on-going negotiations within the partnership cannot be said.

Significantly, alongside the higher proportion of men responsible for running the household, the data for cohabitation also indicated a shift towards egalitarianism. This would confirm our basic hypothesis about less investment and less specialisation within cohabitation. However, the shift towards egalitarianism is not as strong as the shift towards male responsibility for the household, and thus the increased presence of a 'non-traditional' female breadwinner in cohabitation is stronger than the increase in egalitarianism in the partnership. 
DANA HAMPLOVÁ graduated from the Faculty of Arts of Charles University with a degree in Sociology and Czech Linguistics and Literature. At present she is enrolled in post-graduate studies in Sociology at the same faculty. She works as a researcher at the Institute of Sociology of Academy of Sciences (Prague) and participates in the Globlife project of the University of Bamberg. Her main research interests are the sociology of the family and the sociology of religion.

\section{References}

Axinn, W., A. Thornton 1992. "The Relationship Between Cohabitation and Divorce: Selectivity or Casual Influence?” Demography 29: 357-374.

Becker, G.S. 1993. A Treatise on the Family. Cambridge, Massachusetts, London, England: Harvard University Press.

Berger, P. L., H. Kellner 1979. Facing up to Modernity. Harmondworth: Penguin Books.

Blackwell, D. L., D.T. Lichter 2000. "Mate Selection among Married and Cohabiting Couples”. Journal of Family Issues Vol. 21 (3): 275-303.

Blau, P. 1964. Exchange and Power in Social Life. New York: Jon Wiley and Sons.

Blumstein, P., P. Schwartz 1983. American Couples: Money, Work, and Sex. New York: Morrow.

Brines, J., K. Joyner 1999. “The Ties That Bind: Principles of Cohesion in Cohabitation and Marriage”. American Sociological Review 64: 333-355.

Brown, S., A. Booth 1996. "Cohabitation versus Marriage: A Comparison of Relationship Quality”. Journal of Marriage and the Family 5, 3: 668-679.

Bumpass, L. L., J. A. Sweet 1989. "National Estimates of Cohabitation”. Demography 26: 615-625.

Carmichael, G. 1995. "Consensual Partnering in the More Developed Countries". Journal of the Australian Population Association 121: 51-86.

Clarberg, M. 1999. "The Price of Partnering: The Role of Economic Well-being in Young Adults' First Union Experiences”. Social Forces 77, 3: 945-969.

DeMaris, A., W. MacDonald 1993. "Premarital Cohabitation and Marital Instability : A Test of the Unconventionality Hypothesis". Journal of Marriage and the Family 55, 2: 399-408.

DeMaris, A., K.V. Rao 1992. "Premarital Cohabitation and Subsequent Marital Stability in the United States: A Reassessment”. Journal of Marriage and the Family 54, 1: 178-201.

De Santis, Livi Bacci. 2001. "Reflections on the Economics of the Fertility Decline in Europe". Euresco Conference, The Second Demographic Transition in Europe, Bad Herrenalb, Germany, 23-28 June 2001.

Hamplová, D., S. Pikálková, J. Rychtaříková 2001. “Diferenciace reprodukčního a rodinného chování v evropských populacích" ["Differentiation of Reproductive and Family Behaviour in the Populations of Europe”]. Sociological Papers 01:10, Praha: Sociologický ústav AV ČR.

Horwitz, A.V., White, H.R. 1998. "The Relationship of Cohabitation and Mental Health: A Study of a Young Adult Cohort". Journal of Marriage and the Family 60, 2: 505-515

Kiernan, K. 2000. "European Perspectives on Union Formation”. Pp. 54-78 in The Ties that Bind. Perspectives on Marriage and Cohabitation, edited by L.J. Waite. New York: Aldine de Gruyter. 
Kučera, M. 1994. Populace České republiky 1918-1991. (The Population of the Czech Republic 1918-1991). Praha: Sociologický ústav AV ČR.

Manning W.D., D.T. Lichter 1996. "Parental Cohabitation and Children's Economic Well-being". Journal of Marriage and the Family 58: 998-1010.

Oppenheimer, V. K., L. Nelson 1997. "Men's Career Development and Marriage Timing During a Period of Rising Inequality”. Demography 34: 311-330.

Rabušic, L. 2001. Kde ty všechny děti jsou? (Where Have All the Kids Gone?) Praha: Sociologické nakladatelství.

Rabušic, L. 1996. “O současném vývoji manželského a rodinného chování v České republice“ (On Current Developments in Marriage and Family Behaviour in the Czech Republic). Demografie 38, 3: 173-180.

Rindfuss, R.R., A. VandenHeuvel 1990. "Cohabitation: Precursor to Marriage or an Alternative to Being Single?" Population and Development Review 16: 703-726.

Schoen R., Weinick, R. 1993. "Partner Choices in Marriage and Cohabitations". Journal of Marriage and the Family 55: 408-414.

South, S.J., G. Spitze 1994. "Housework in Marital and Nonmarital Households". American Sociological Review 59, 327-347.

Stack, S., J.R. Eshleman 1998. "Marital Status and Happiness: A 17-Nations Study". Journal of Marriage and the Family 60, 2: 527-537.

Thomson, E., U. Collela 1992. "Cohabitation and Marital Stability: Quality or Commitment?" Journal of Marriage and the Family 54, 2: 259-268

Vereš, P. 1991. "Několik úvah o současném a budoucím populačním vývoji“" [Some Thoughts on the Present and Future Population Development]. Demografie 33, 2: 97-104. 